\title{
Approaches to classifying and restoring degraded tropical forests for the anticipated REDD+ climate change mitigation mechanism
}

\author{
Sasaki N ${ }^{(1-2)}$, Asner GP ${ }^{(3)}$, Knorr W ${ }^{(4)}$, Durst PB ${ }^{(5)}$, Priyadi HR ${ }^{(6-7)}$, \\ Putz FE ${ }^{(8)}$
}

Inclusion of improved forest management as a way to enhance carbon sinks in the Copenhagen Accord of the United Nations Framework Convention on Climate Change (December 2009) suggests that forest restoration will play a role in global climate change mitigation under the post-Kyoto agreement. Although discussions about restoration strategies often pertain solely to severely degraded tropical forests and invoke only the enrichment planting option, different approaches to restoration are needed to counter the full range of degrees of degradation. We propose approaches for restoration of forests that range from being slightly to severely degraded. Our methods start with ceasing the causes of degradation and letting forests regenerate on their own, progress through active management of natural regeneration in degraded areas to accelerate tree regeneration and growth, and finally include the stage of degradation at which re-planting is necessary. We argue that when the appropriate techniques are employed, forest restoration is cost-effective relative to conventional planting, provides abundant social and ecological co-benefits, and results in the sequestration of substantial amounts of carbon. For forest restoration efforts to succeed, a supportive post-Kyoto agreement is needed as well as appropriate national policies, institutional arrangements, and local participation.

Keywords: Assisted natural regeneration, Biodiversity, Climate change agreement, Forest restoration, REDD-plus, Reduced-impact logging, Silviculture

(1) Graduate School of Applied Informatics, University of Hyogo, 650-0044 Kobe (Japan); (2) Harvard Forest, Harvard University, MA-01366 Petersham (USA); (3) Department of Global Ecology, Carnegie Institution for Science, CA-94305 Stanford (USA); (4) QUEST, Department of Earth Sciences, University of Bristol, BS81RJ Bristol (UK); (5) Food and Agriculture Organization of the United Nations, Regional Office for Asia and the Pacific, Bangkok (Thailand); (6) Center for International Forestry Research (CIFOR), P.O. Box 0113, BOCBD Bogor 16000 (Indonesia); (7) Southern Swedish Forest Research Centre, Swedish University of Agricultural Sciences, P.O. Box 49, SE-230 53 Alnarp (Sweden); (8)

Department of Biology, University of Florida, FL 32611 Gainesville (USA).

@ Nophea Sasaki (nop.kankyo@ai.uhyogo.ac.jp)

Received: Aug 28, 2010 - Accepted: Nov 19, 2010

Citation: Sasaki N, Asner GP, Knorr W, Durst PB, Priyadi HR, Putz FE, 2011. Approaches to classifying and restoring degraded tropical forests for the anticipated REDD+ climate change mitigation mechanism. iForest 4: 1-6 [online 2011-01-27] URL:

http://www.sisef.it/iforest/show.php? id $=556$

\section{Introduction}

Tropical forests support much of the Earth's biological diversity and contribute substantially to the global economy, to local human welfare, and to the global carbon budget. Based on 109 case studies from across the tropics (TEEB Climate Issues Update 2009 as cited in Sukhudev 2010), if all the ecosystem services provided by tropical forests were paid for, they would generate about US\$ 11.1 trillion year $^{-1}$ (US\$ 6.120 $\mathrm{ha}^{-1} \cdot 1807$ million ha), nearly equivalent to the European Union's GDP in 2009. Unfortunately, the capacity of tropical forest to provide these services is reduced each year by deforestation (Lambin et al. 2003, FAO 2010) as well as by degradation principally due to uncontrolled logging (Gaston et al. 1998, Asner et al. 2009, Asner et al. 2010, FAO 2006, Tacconi 2007) and fires (Nepstad et al. 1999, Siegert et al. 2001). With regard to degradation, at least 392 million ha, or $20 \%$ of the total area of humid tropical forests, were logged during 2000-2005, and about $50 \%$ of standing humid tropical forests retained $50 \%$ or less cover as of 2005 (Asner et al. 2009, FAO 2010). The limited data available on carbon emissions due to forest degradation suggest that they double the 1.52.2 ${\mathrm{PgC} \mathrm{yr}^{-1}}^{-1}$ released by deforestation (Asner et al. 2010, Gullison et al. 2007, Houghton 2003, Putz \& Nasi 2009). Furthermore, deforestation and forest degradation also affect $89 \%$ of all threatened birds, $83 \%$ of threatened mammals, and $91 \%$ of threatened plants (http://www.iucn.org/).

There is growing recognition of and increasing interest in generating carbon credits through reducing emissions from deforestation and forest degradation with enhancement of carbon sinks (REDD+), as evident by the recognition in the Copenhagen Accord adopted at the $15^{\text {th }}$ Conference of the Parties (COP15) to the United Nations Framework Convention on Climate Change (UNFCCC 2009) in December 2009. Unfortunately, most of the international attention has focused on avoided deforestation (Kindermann et al. 2008, Gullison et al. 2007) and enhancement of carbon sinks through reforestation and afforestation (Thomas et al. 2010) either within or outside the framework of the Kyoto Protocol. Much less attention has been paid to halting and reversing forest degradation through restoration, interventions that in addition to increased forest carbon stocks have many collateral benefits including the improved capacity of forest lands to provide other ecosystem services, support biodiversity, and contribute to social welfare. With negotiations about REDD+ intensifying, an urgent issue now is how to restore degraded forests in socially viable, environmentally acceptable, and economically costeffective manners. Restoration strategies should be a key element of any REDD+ agreement, and therefore such strategies need to be clarified. Here we focus on the causes of degradation, propose a classification scheme that reflects the severity of degradation, and point to ways to restore degraded forests that are appropriate for the classes proposed.

\section{Defining "Forest" for the purposes of reversing forest degradation}

For the purposes of elucidating forest degradation, we adopt the UNFCCC's definition of "forest" and the linked definitions of "deforestation" and "forest degradation" (Marrakesh Accord, Decision 11/CP.7) in full recognition of their limitations (Sasaki \& Putz 2009, Hance 2010, Putz \& Redford 2010). Although we are particularly concerned about the lack of reference to species composition in this definitions, we take a "forest" to be an area of $>0.05$ ha with tree crown cover $>20 \%$ with a "tree" defined as a plant with the capacity to grow to $>3 \mathrm{~m}$ tall. It follows then that "forest degradation" is the loss of trees and their carbon stocks down to the point that an area no longer qualifies as being forested, at which point the area is "deforested." We further define 
"restoration" as management activities that help degraded forests recover their lost carbon stocks, biodiversity, and capacities to provide other goods and environmental services.

\section{Restoration strategies and approaches}

Tropical forests are degraded in ways that reduce tree cover and carbon stocks principally by indiscriminate logging (Asner et al. 2006, 2010), fires (Page et al. 2002, Aragão \& Shimabukuro 2010), shifting cultivation (Lawrence 2005), and harvesting trees for charcoal production (Ahrends et al. 2010). To counter the effects of degradation, whatever the causes and regardless of the degrees, tree planting is often prescribed (Lamb et al. 2005, Chazdon 2008). Without denying the value of tree planting where seed sources have been eliminated and degradation is otherwise severe, there are other approaches to forest restoration that are often more cost-effective and that engender fewer ecological concerns (Ganz \& Durst 2003 Letcher \& Chazdon 2009, Peña-Claros et al. 2008, Shono et al. 2007a, Vieira et al. 2009, Villegas et al. 2009, Zimmerman et al. 2007). By categorizing forests on the basis of degrees of degradation (Fig. 1), we can select from among these approaches with more assurance of success in terms of low financial costs, better biodiversity conservation, and broad social and environmental benefits.

To facilitate communication about restoration strategies for forests modified from their primary, old growth, or mature condition $\left(\mathrm{P}_{0}\right.$ in Fig. 1), we define the following arbitrary set of states. Forests in state A are slightly degraded but retain some trees above the minimum diameter at breast height $(\mathrm{DBH})$ for legal harvesting (DBH limits for tropical countries are provided in Tab. SM1 of the Supplementary Materials). Forests in state B are moderately degraded due to having lost their legally harvestable trees but retain many that are just smaller than the minimum cutting diameter (for legal harvest). Forests in state $\mathrm{C}$ are highly degraded insofar as they contain only trees much smaller than the minimum cutting diameter. Finally, forests in state D are critically degraded insofar as they have few residual trees of any size (but enough for the area to still be considered "forest" - Fig. 2).

To provide rough estimates of the carbon stocks lost from forests degraded from point A to point D, data from Cambodia (Kao \& Iida 2003, Kim Phat et al. 2000), Indonesia (Sist \& Saridan 1998), Brazil (Wellhöfer 2002, Nascimentoa \& Laurance 2002), and Panama (Chave et al. 2003) suggest restorable losses of above-ground carbon stocks of 26.3 to $173.0 \mathrm{MgC} \mathrm{ha}^{-1}$ with an average of 112.4 MgC (Fig. 3 and Tab. 1). Depending

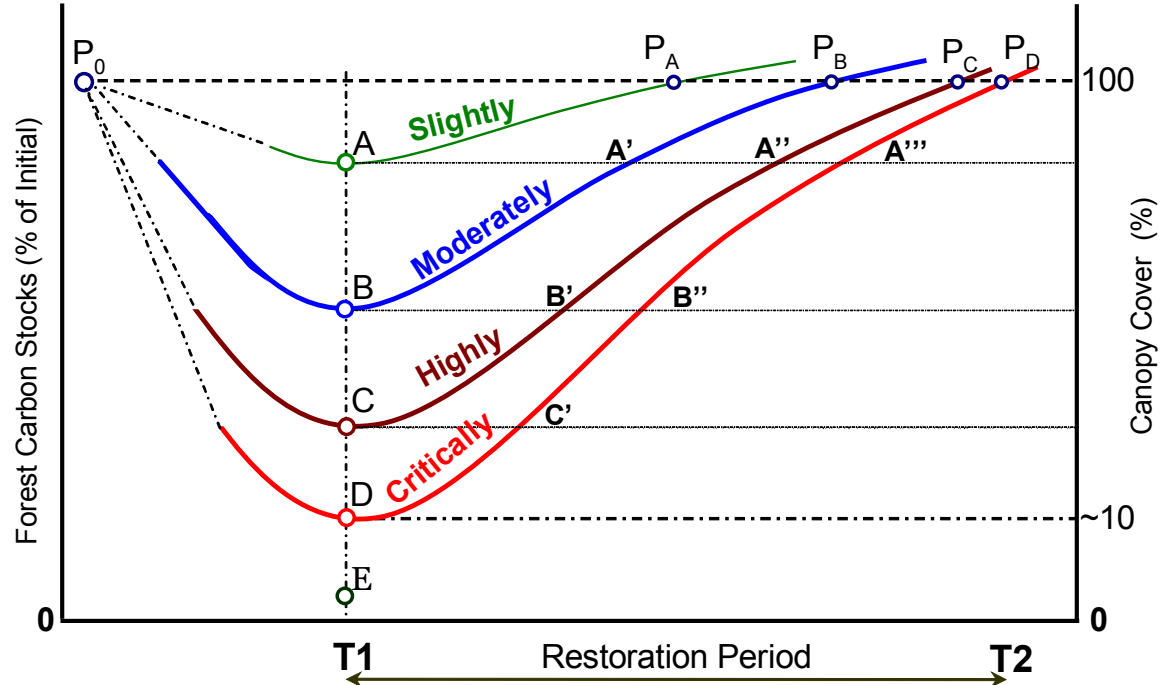

Fig. 1 - Schematic diagram of different states of forest degradation and time courses for restoration. The right and left $\mathrm{Y}$-axes represent different degrees of degradation expressed qualitatively as carbon stocks and percent canopy cover, respectively. $\left(\mathrm{P}_{0}\right)$ : pre-harvest level of primary or old growth forest; (A): only authorized trees are harvested; (B): all trees larger than the minimum diameter for cutting are harvested; (C): all marketable trees are harvested; (D): no longer forest according to forest definition adopted by the UNFCCC in 2001 (Marrakesh Accord, Decision 11/CP.7); (E): Deforested. (D to E) is eligible for reforestation or afforestation under the clean development mechanism (CDM) if deforested prior to 1989 or 1940, respectively; (A to D): degradation; (D to E): deforestation; (T1 -T2): restoration period. Negotiations to include avoiding deforestation and degradation (AE) are underway. on the degree of degradation, ecological characteristics of the residual species, needs and preferences of critical forest stakeholders, availability of funds, and accessibility, any of three general approaches to restoration can be appropriate, presented below in reference to these categories of degraded forest.

\section{Restoring slightly degraded forest ( $S D F, P_{0}$ to $A$ to $\left.P_{A}\right)$}

SDF refers to areas where timber harvesting was restricted to the legally permitted fraction of trees and only occurred in accordance with government-specified minimum cutting cycles or at longer intervals. The degradation is due to regulated harvests being

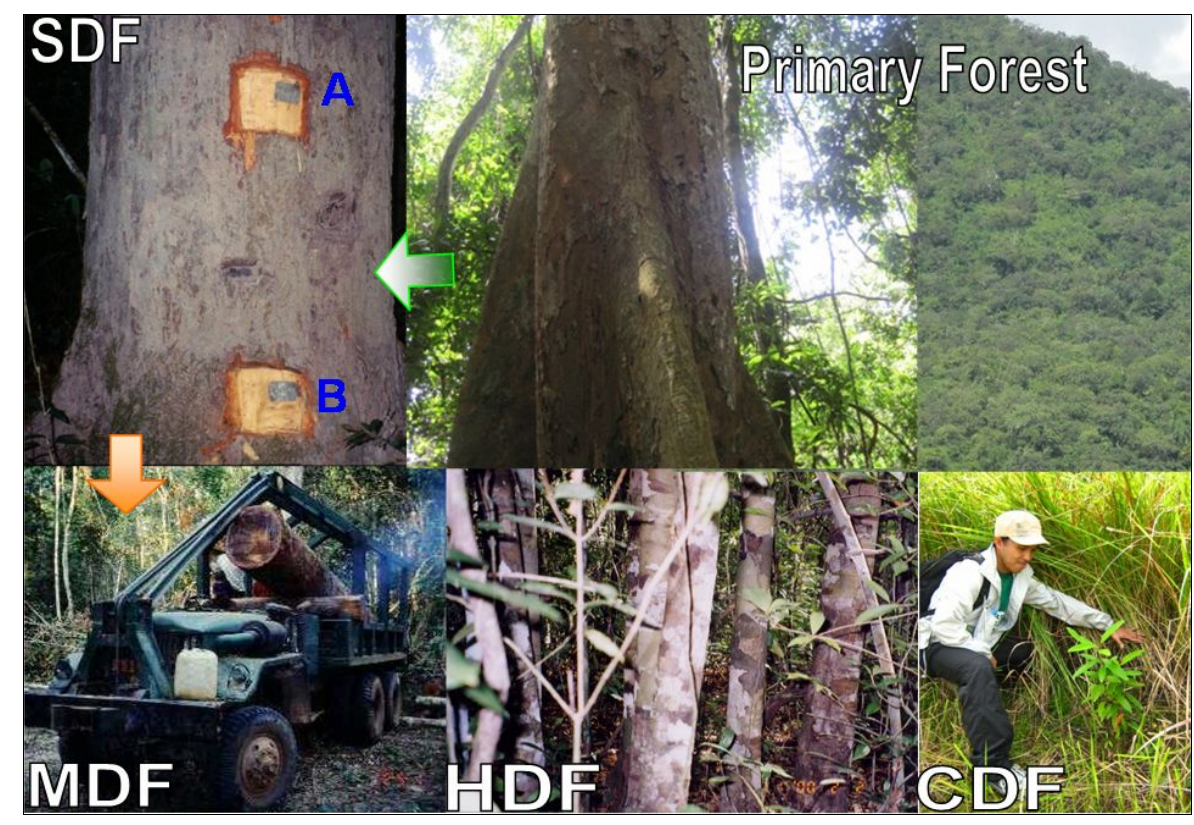

Fig. 2 - Primary and degraded natural forests. Points A \& B are tags on a mature tree that was authorized for felling in Cambodia. Tree species, DBH, block, and coupe numbers are noted on each tag. To be considered legal, the feller must cut this tree between the two tags. All felled trees without such tags are considered illegal. 


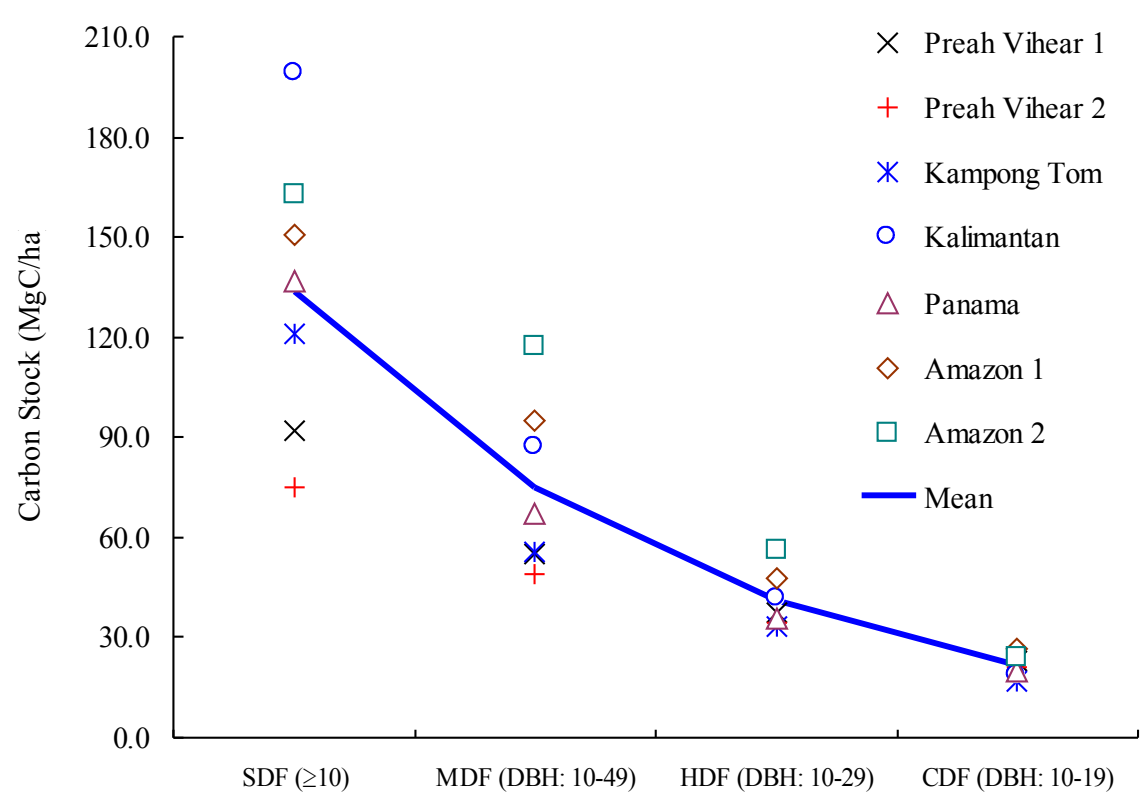

Forest Categories

Fig. 3 - Above-ground carbon stocks in slightly (SDF), moderately (MDF), highly (HD), and critically (CDF) degraded forests. If CDF can be gradually restored back to the SDF, more carbon will be sequestered and stored in the forest. Note 1: due to variations in carbon stocks in various forest types across the tropics, here in the Fig. 3, we assume that SDF, MDF, $\mathrm{HDF}$, and CDF contains trees with $\mathrm{DBH} \geq 10 \mathrm{~cm}, 10-49 \mathrm{~cm}, 10-29 \mathrm{~cm}$, and $10-19 \mathrm{~cm}$, respectively. With these assumptions, carbon stocks in relevant degraded forests are shown in the Fig. 3 above. Note 2: Data for Preah Vihear 1 (unlogged forest in Preah Vihear province, Cambodia), Preah Vihear 2 (logged forest in Preah Vihear province, Cambodia) were adopted from Kao \& Iida (2003); data for forests in Kampong Tom province, Cambodia were adopted from Kim Phat et al. (2000); data for forest in Kalimantan (East Kalimantan, Indonesia) were taken from Sist and Saridan (1998); data for forests in Panama were adopted from Chave et al. (2003); data for Amazon 1 and Amazon 2 were adopted from Wellhöfer (2002) and Nascimentoa \& Laurance (2002), respectively.

more intensive and more frequent than the forest can biologically sustain, at least in the absence of silvicultural treatments, as well as due to harvesting by untrained and inadequately supervised workers operating without the aid of adequate harvest plans. The consequent reductions in carbon stocks and high-value tree species are represented

by the transition from points $\mathrm{P}_{0}$ to $\mathrm{A}$.

To restore SDF, we propose reductions in logging intensities, avoidance of timber harvesting from steep slopes and other environmentally sensitive areas, and lengthening of cutting cycles, as appropriate, coupled with the use of reduced-impact logging techniques and liberation treatments of future

Tab. 1 - Average above-ground carbon stocks in tropical forests and percentages. - Note: Data in Tab. 1 were derived from two sites in Brazil (Wellhöfer 2002, Nascimentoa \& Laurance 2002), three sites in Cambodia

\begin{tabular}{|c|c|c|c|c|}
\hline \multirow{2}{*}{$\begin{array}{l}\text { Carbon } \\
\text { Stocks }\end{array}$} & \multicolumn{4}{|c|}{ Category } \\
\hline & $\begin{array}{c}\text { SDF } \\
(D B H \geq 10 \mathrm{~cm})\end{array}$ & $\begin{array}{c}\text { MDF } \\
\text { (DBH: } 10-49 \mathrm{~cm} \text { ) }\end{array}$ & $\begin{array}{c}\text { HDF } \\
\text { (DBH: } 10-29 \mathrm{~cm} \text { ) }\end{array}$ & $\begin{array}{c}\text { CDF } \\
\text { (DBH: } 10-19 \mathrm{~cm} \text { ) }\end{array}$ \\
\hline \multicolumn{5}{|c|}{ Above-ground carbon stocks $\left(\mathrm{MgC} \mathrm{ha}^{-1}\right)$} \\
\hline Min & 75.3 & 49.0 & 33.1 & 17.1 \\
\hline Max & 199.4 & 117.2 & 56.6 & 26.3 \\
\hline Mean & 134.0 & 75.2 & 41.0 & 21.6 \\
\hline \multicolumn{5}{|c|}{ Percentage of above-ground carbon stocks (\%) } \\
\hline Min & 100.0 & 65.1 & 44.0 & 22.7 \\
\hline Max & 100.0 & 58.8 & 28.4 & 13.2 \\
\hline Mean & 100.0 & 56.1 & 30.6 & 16.1 \\
\hline
\end{tabular}

crop trees in the residual stand. These changes in management practices that serve to reduce wood waste and logging damage, and to increase the growth of future crop trees are termed reduced-impact logging plus silviculture (RIL+; refer to Table SM1 in the Supplementary Materials for explanations of terms and impacts of various logging practices in the tropics). RIL+ involves worker training, harvest planning, site preparation, directional felling, and use of appropriate equipment for log yarding. Liberation treatments might include mechanical girdling and/or killing with herbicides of non-commercial trees that overtop future crop trees, plus vine cutting to accelerate the recruitment and growth of trees that have the capacity to grow to be large. Such treatments can accelerate average tree growth by $9-27 \%$ for all tree species, and by $50-60 \%$ for future crop trees (Peña-Claros et al. 2008, Villegas et al. 2009); application of such treatments to a selectively logged forest in Amazonian Brazil doubled the annual rate of aboveground biomass recovery from 0.16 to 0.33 $\mathrm{Mg} \mathrm{C} \mathrm{ha-1} \mathrm{yr}^{-1}$ (see SM for calculations) during at least the initial 6 years following logging (Wadsworth \& Zweede 2006). It is important to note, however, that in Indonesia, the benefits of RIL for the residual stand disappeared where the logging intensity was $>8$ trees $\mathrm{ha}^{-1}$ (Sist et al. 2003). Reduced felling intensities benefits not only regeneration and growth of the residual stand, but also the long-term ecological sustainability of forest management operations.

Restoring moderately degraded forest $\left(\mathrm{MDF}, \mathrm{P}_{0}\right.$ to $\mathrm{B}$ to $\left.\mathrm{P}_{B}\right)$

In MDF, more commercially high-value trees are harvested than authorized, and excessively damaging logging practices are employed. Unfortunately, failure to enforce forest management regulations is commonplace in the tropics (Gustafsson et al. 2007) and results in substantial but avoidable losses in forest carbon stocks (down to point B on Fig. 1). These logging practices result in substantial losses of commercially highvalue timber species (Uryu et al. 2008) and substantial canopy opening, which renders forests susceptible to further degradation by drought and fires. MDF still contains some intermediate size trees, some of which are reproductively mature, and some large trees with defective stems, but carbon stocks are reduced by half of that in SFD (Tab. 1). MDF requires human intervention to protect the intermediate size trees and accelerate their growth. Forests in this category could be restored by active liberation and other silvicultural treatments to enhance the growth of future crop trees (B to A'), or more passively by preventing pre-mature re-entry logging and the continued use of poor logging practices $\left(\mathrm{A}^{\prime}\right.$ to $\left.\mathrm{P}_{\mathrm{B}}\right)$. 
Restoring highly degraded forest (HDF, $P_{0}$ to $C$ to $P_{C}$ )

In HDF even trees smaller than the legalsize limit (see Tab. SM2) and reproductively mature trees of low financial value were harvested presumably in response to strong demand for timber and fuelwood coupled with weak governance. Due to substantial canopy opening caused by excessive and repeated tree harvesting, such forests are very susceptible to further degradation by fire or grazing coupled with invasion by fire-favoring graminoids. HDF is assumed to still contain some small residual forest trees, but carbon stocks are further reduced from those in MDF (Tab. 1). Restoration of HDF requires the cessation of the causes of degradation (B' to A") followed by intensive liberation treatments to stimulate the growth of trees with the capacity to grow to large sizes In forests allocated for timber production, one goal is to bring the degraded forest back to a point where there are some sound trees larger than the legal limit for harvesting $(C$ to $\left.\mathrm{B}^{\prime}\right)$; if natural regeneration and seed trees of heavily exploited species are too scarce, enrichment planting with native species might be justified.

Restoring critically degraded forest (CDF, $P_{0}$ to $D$ to $\left.P_{D}\right)$

$\mathrm{CDF}$ corresponds to areas that barely qualify as forest under the UNFCCC's definition and that are at the ecological threshold from which unassisted recovery is unlikely (Lamb et al. 2005). CDFs have been stripped of most trees by over-harvesting of timber and fuelwood collection, and are often burned, overgrazed, and dominated by lianas, shrubs, giant herbs, graminoids, or other nonarboreal species, both native and exotic. At point $\mathrm{D}$, the risk of further degradation and transformation to non-forest land is generally very high (Du Toit et al. 2004). CDF stil contains some small trees, but carbon stocks are reduced to $<20 \%$ of SDF values (Tab $1)$. Initial restoration of such areas begins with stopping the causes of degradation and allowing natural recovery processes to proceed, but such processes often need to be accelerated by various forms of more active restoration. The restoration strategies recommended for moving from point $\mathrm{D}$ to $\mathrm{C}$ ' generally involve replanting (e.g., Lamb et al 2005, Chazdon 2008, and Shono et al. $2007 \mathrm{~b}$ ), which is costly and therefore unlikely to be widely implemented. Based on various studies across the tropics (e.g., Ganz \& Durst 2003, Shono et al. 2007a), "assisted natural regeneration" is likely to be more cost-effective than replanting, thus making large-scale implementation more feasible. This approach might include fire management, grazing restrictions, suppressing the growth of invasive and fire-favoring graminoids (e.g., Imperata cylindrica, Pennisetum purpureum, and Urochloa maxima), protecting naturally regenerated native tree species, weeding, fertilizing, and, if necessary, interplanting of native or even exotic nitrogenfixing trees. Depending on geographic locations and forest conditions, another possible approach is to apply an "agro-successional" restoration approach that has proven effective with forest-dependent communities that farm (Vieira et al. 2009). Agro-successional approach involves the use of a "taungya" system in which native tree species are interplanted with annual crops; after two or so food crops have been harvested, the trees come to dominate the area and the farmers move to another area to repeat the process. Eventually, thinning may be needed to accelerate the growth of desired individuals, thus speeding the transition from point C' to B'. The residues from pruning and thinning might be used for forage or fuelwood by nearby communities. With increasing forest stature, stopping the causes of degradation continues to be important as the recovery proceeds from B" to A". Eventually, during the final restoration phase (A" to $\left.\mathrm{P}_{\mathrm{D}}\right), \mathrm{RIL}+$ treatments become appropriate.

\section{Making these strategies work}

A major constraint on the success of restoration interventions is the continued availability of funding, but some of the options we describe are not expensive to implement. For example, the switch from excessively destructive to reduced-impact logging reportedly ranges from having slight negative (Tay et al. 2002) to large positive effects on profits from timber harvesting (Holmes et al. 2002). Depending on geographical location, season, and equipment, costs for liberation treatments by girdling of unwanted trees are likewise modest; in Bolivia they were estimated at US\$ 0.21-1.04 per tree or about US\$ 5.08-25.17 ha ${ }^{-1}$ (Ohlson-Kiehn et al. 2006; this assumes girdling of 24.2 competing trees $\mathrm{ha}^{-1}$ on average, based on Wadsworth \& Zweede 2006). The costs of restoration using assisted natural regeneration techniques are far less than enrichment planting and other conventional plantation development techniques because the costs of propagating, raising, and planting seedlings are avoided (Ganz \& Durst 2003, Shono et al. 2007a). Average costs of ANR in three sites in the Philippines are approximately US\$ $579 \mathrm{ha}^{-1}$ compared to US\$ $1.048 \mathrm{ha}^{-1}$ for conventional reforestation methods (Durst et al. 2010). Furthermore, forests resulting from assisted natural regeneration are more biologically diverse and provide more benefits to local people than plantations. As restoration proceeds, more long-term benefits from ecosystem services and employment are expected, especially where efforts are financially supported by either the voluntary carbon market or funds from a future REDD+ agreement.
Financial support for the latter is pledged at US\$ 3.5 billion annually between 2010 and 2012 (Grassi et al. 2010) and more is likely for an expected post-Kyoto implementation period between 2013 and 2020. Successful implementation of payments for ecosystem services for restoring forests in Costa Rica (Pagiola 2008, Calvo-Alvarado et al. 2009) and in South America (Turpie et al. 2008) provide evidence in support of the financial viability of our proposed approaches to restoration.

Effective and efficient monitoring and verification are essential to any global program that includes halting degradation and restoration among possible climate mitigation strategies. The framework we propose fits well with the latest techniques in satellite monitoring that allow direct estimation of canopy loss, recovery, and closure at a range of logging intensities (Asner et al. 2006, Curran \& Trigg 2006, GOFC-GOLD 2009). Moreover, the next generation of biomasssensitive satellite sensors will soon be launched, with many more planned (GOFCGOLD 2009), which further supports the proposed strategy. Due to technological advancements and the availability of free data, the costs for monitoring carbon stocks and emissions are already as low as US\$ 0.06 $\mathrm{ha}^{-1}$ in Madagascar, and US\$ $0.08 \mathrm{ha}^{-1}$ in Amazonian Peru (Asner et al. 2010)

\section{Conclusions}

Restoring degraded tropical forests has a huge potential for mitigating global climate change by enhancing carbon stocks. Among the approaches discussed, the first is to stop the causes of degradation and allow forests to regenerate on their own. The second approach is to accelerate tree regeneration and growth through application of any of a variety of silvicultural treatments. The third general approach is to plant seeds or seedlings in natural or artificial gaps, a process often referred to as enrichment planting. To promote widespread implementation of these strategies under REDD+ initiatives, appropriate incentives, policies, institutional arrangements, and local participation are required. Since restoration takes time, longterm political commitments by participating countries will be required. REDD+ funded forest restoration will contribute to sustainable development and help secure the ecosystem services upon which billions of people depend.

\section{Acknowledgements}

We thank D. R. Foster., B. A. Colburn, K. Tanaka, B. B. Eav, M. Suwa, D. Orwig, and S. Seng for helpful comments, and S. Ouk, S. Ty, and E. Cadaweng for photos. N. Sasaki was supported through the Harvard Forest's Charles Bullard Fellowship in Forest Research for Advanced Research. G. 
Asner was supported by the Gordon and Betty Moore Foundation.

\section{References}

Ahrends A, Burgess ND, Milledge SA, Bulling MT, Fisher B, Smart JC, Clarke GP, Mhoro BE, Lewis SL (2010). Predictable waves of sequential forest degradation and biodiversity loss spreading from an African city. Proceedings of the National Academy of Sciences USA 107: 14556-14561. - doi: 10.1073/pnas.0914471107

Aragão EOCL, Shimabukuro EY (2010). The incidence of fire in Amazonian forests with implications for REDD. Science 328: 1275-1278. - doi: 10.1126/science. 1186925

Asner GP, Broadbent EN, Oliveira PJ, Keller M, Knapp DE, Silva JN (2006). Condition and fate of logged forests in the Brazilian Amazon. Proceedings of the National Academy of Sciences USA 103: 12947-12950. - doi: 10.1073/ pnas.0604093103

Asner PG, Rudel KT, Aide TM, De Fries R, Emerson R (2009). A contemporary assessment of change in humid tropical forests. Conservation Biology 23: 1386-1395. - doi: 10.1111/j.15231739.2009.01333.x

Asner GP, Powell GVN, Mascaro J, Knapp DE, Clark JK, Jacobson J, Kennedy-Bowdoin T, Balaji A, Paez-Acosta G, Victoria E, Secada L, Valqui M, Hughes FR (2010). High-resolution carbon stocks and emissions in the Amazon. Proceedings of the National Academy of Sciences USA 107: 16738-16742. - doi: 10.1073/ pnas. 1004875107

Calvo-Alvarado J, McLennan B, Sánchez-Azofeifa A, Garvin A (2009). Deforestation and forest restoration in Guanacaste, Costa Rica: Putting conservation policies in context. Forest Ecology and Management 258: 931-940. - doi: 10.1016/j.foreco.2008.10.035

Chave J, Condit R, Lao S, Caspersen JP, Foster RB, Hubbell PS (2003). Spatial and temporal variation of biomass in a tropical forest: results from a large census plot in Panama. Journal of Ecology 191: 240-252. - doi: 10.1046/j.13652745.2003.00757.x

Chazdon RL (2008). Beyond deforestation: restoring forests and ecosystem services on degraded lands. Science 320: 1458-14560. - doi 10.1126/science. 1155365

Curran LM, Trigg SN (2006). Sustainability science from space: quantifying forest disturbance and land-use dynamics in the Amazon. Proceedings of the National Academy of Sciences, USA 103: 12663-12664. - doi: 10.1073/pnas. 0605449103

Durst PB, Sajise P, Leslie RN (2010). Forests beneath the grass. In: "Proceedings of the regional workshop on advancing the application of assisted natural regeneration for effective low-cost restoration. Bohol (Philippines) 19-22 May 2009. RAP Publication 2010/11, FAO, Bangkok, Thailand.

FAO (2006). Global forest resources assessment 2005. FAO Forestry Paper 147, FAO, Rome. FAO (2010). Global forest resources assessment
2010. Main Report. FAO Forestry Paper 163, FAO, Rome.

Ganz DJ, Durst PB (2003). Assisted natural regeneration: an overview. In: "Advancing assisted natural regeneration (ANR) in Asia and the Pacific" (Dugan PC, Durst PB, Ganz DJ, McKenzi PJ eds). FAO Regional Office for Asia and the Pacific, Bangkok, Thailand, pp. 1-4.

Gaston G, Brown S, Lorenzini M, Singh KD (1998). State and change in carbon pools in the forests of tropical Africa. Global Change Biology 4: 97-114. - doi: 10.1046/j.1365-2486.1998. 00114.x

GOFC-GOLD (2009). Reducing greenhouse gas emissions from deforestation and degradation in developing countries: a source book of methods and procedures for monitoring, measuring and reporting. Report version COP14-2, GOFCGOLD Project Office, Natural Resources Canada, Alberta, Canada.

Grassi G, Federici S, Pilli R (2010). What happened to forests in Copenhagen? iForest 3: 30-32. - doi: 10.3832/ifor0529-003

Gullison FR, Frumhoff CP, Canadell GJ, Field CB, Nepstad DC, Hayhoe K, Avissar R, Curran LM, Friedlingstein P, Jones CD, Nobre C (2007). Tropical forests and climate policy. Science 136: 985-986. - doi: 10.1126/science.1136163

Gustafsson L, Nasi R, Dennis R, Nguyen Hoang Nghia, Sheil D, Meijaard E, Dykstra D, Priyadi, H, Pham Quang Thu (2007). Logging for the ark: improving the conservation value of production forests in South East Asia. CIFOR Occasional paper 48, CIFOR, Bogor, Indonesia.

Hance J (2010). Rainforest scientists urge UN to correct "serious loophole" by changing its definition of "forest". Web site. [online] URL: http://news.mongabay.com/2010/0624-hance atbc_forests.html

Holmes TP, Blate GM, Zweede JC, Pereira R, Barreto P, Boltz F, Bauch R (2002). Financial and ecological indicators of reduced impact logging performance in the eastern Amazon. Forest Ecology and Management 163: 93-110. - doi: 10.1016/S0378-1127(01)00530-8

Houghton RA (2003). Revised estimates of the annual net flux of carbon to the atmosphere from changes in land use and land management 18502000. Tellus 55B: 378-390. - doi: 10.1034/ j.1600-0889.2003.01450.x

Kao D, Iida S (2003). Structural characteristics of logged evergreen forests in Preah Vihear, Cambodia, 3 years after logging. Forest Ecology and Management 225: 62-73. - doi: 10.1016/j.foreco.2005.12.056

Kim Phat N, Ouk S, Uozumi Y, Ueki T (2000). Stand dynamics of dipterocarp trees in Cambodia's evergreen forest and management implications; a case study in Sandan District, Kampong Thom. Journal of Forest Planning 6: 13-23. [online] URL: http://www.mekonginfo.org/mrc_en/ doclib.nsf/0/60aa22a74d627e76472569d50013c5 f5/\$file/fulltext.html

Kindermann G, Obersteiner M, Sohngen B, Sathaye J, Andrasko K, Rametsteiner E, Schlamadinger B, Wunder S, Beach R (2008). Global cost estimates of reducing carbon emissions through avoided deforestation. Proceedings of the National Academy of Sciences USA 105: 10302-10307. - doi: 10.1073/pnas.0710616105

Lambin EF, Geist H, Lepers E (2003). Dynamics of land use and cover change in tropical regions. Annual Review of Environment and Resources 28: 205-241. - doi: 10.1146/annurev.energy. 28.050302.105459

Lamb D, Erskine PD, Parrotta JA (2005). Restoration of degraded tropical forest landscapes. Science 310: 1628-1632. - doi: 10.1126/science. 1111773

Lawrence D (2005). Biomass accumulation after 10-200 years of shifting cultivation in Bornean rain forest. Ecology 86: 26-33. - doi: 10.1890/030564

Letcher SG, Chazdon RL (2009). Rapid recovery of biomass, species richness, and species composition in a forest chronosequence in northeastern Costa Rica. Biotropica 41: 608-617. - doi: 10.1111/j.1744-7429.2009.00517.x

Nascimentoa EMH, Laurance FW (2002). Total aboveground biomass in central Amazonian rainforests: a landscape-scale study. Forest Ecology and Management 168: 311-321. - doi: 10.1016/ S0378-1127(01)00749-6

Nepstad D, Veríssimo A, Alencar A, Nobre C, Lefebvre P, Schlesinger P, Potter C, Moutinho P, Lima E, Cochrane M, Brooks V (1999). Large-scale impoverishment of Amazonian forests by logging and fire. Nature 398: 505-508. - doi: $10.1038 / 19066$

Ohlson-Kiehn C, Pariona W, Fredericksen TS (2006). Alternative tree girdling and herbicide treatments for liberation and timber stand improvement in Bolivian tropical forests. Forest Ecology and Management 225: 207-212. - doi: 10.1016/j.foreco.2005.10.075

Page SE, Siegert F, Rieley JO, Boehm HD, Jaya A, Limin S (2002). The amount of carbon released from peat and forest fires in Indonesia during 1997. Nature 420: 61-65. - doi: 10.1038/ nature 01131

Pagiola S (2008). Payments for environmental services in Costa Rica. Ecological Economics 65: 712-724. - doi: 10.1016/j.ecolecon.2007.07.033

Peña-Claros M, Fredericksen TS, Alarcón A, Blate GM, Choque U, Leaño C, Licona JC, Mostacedo B, Pariona W, Villegas Z, Putz FE (2008). Beyond reduced-impact logging: Silvicultural treatments to increase growth rates of tropical trees. Forest Ecology and Management 256: 1458-1467. - doi: 10.1016/j.foreco.2007. 11.013

Putz FE, Nasi R (2009). Carbon benefits from avoiding and repairing forest degradation. In: "Realising REDD+: national strategy and policy options" (Angelsen A ed). Center for International Forestry Research, Bogor, Indonesia, pp. 249262.

Putz FE, Redford HK (2010). Tropical forest definitions, degradation, phase shifts, and further transitions. Biotropica 42: 10-20. - doi: 10.1111/ j.1744-7429.2009.00567.x

Sasaki N, Putz FE (2009). Critical need for new 
definitions of "forest" and "forest degradation" in global climate change agreements. Conservation Letters 2: 226-232. - doi: 10.1111/j.1755263X.2009.00067.x

Shono K, Cadaweng EA, Durst PB (2007a). Application of assisted natural regeneration to restore degraded tropical forestlands. Restoration Ecology 15: 620-626. - doi: 10.1111/j.1526100X.2007.00274.X

Shono K, Davies SJ, Chua YK (2007b). Performance of 45 native tree species on degraded lands in Singapore. Journal of Tropical Forest Science 19: 25-34. [online] URL: http://info.frim.gov.my/ cfdocs/infocenter/Korporat/2003Publications/Lin ks/JTFS\%2019(1)\%202007/Shono.pdf

Siegert F, Ruecker G, Hinrichs A, Hoffmann AA (2001). Increased damage from fires in logged forests during droughts caused by El Niño. Nature 414: 437-440. - doi: 10.1038/35106547

Sist P, Saridan A (1998). Description of the primary lowland forest of Berau. In: "Silvicultural research in a lowland mixed dipterocarp forest of east Kalimantan" (Bertault JG, Kadir K eds). The Contribution of STREK Project. CIRADFORDA-P.T. INHUTANII, pp. 51-94.

Sist P, Sheil D, Kartawinata K, Priyadi H (2003). Reduced impact logging in Indonesian Borneo: some results confirming the needs for new silvicultural precriptions. Forest Ecology and Management 179: 415-427. - doi: 10.1016/S03781127(02)00533-9

Sukhudev P (2010). The economics of biodiversity and ecosystem services in tropical forests. ITTO Tropical Forestry Update 20: 8-10. Tacconi L (2007). Illegal logging: law enforcement, livelihoods and the timber trade. Earthscan, London, UK.

Tay J, Healey J, Price C (2002). Financial assessment of reduced impact logging techniques in Sabah, Malaysia. In "Applying reduced impact logging to advance sustainable forest management" (Enters T, Durst PB, Applegate GB, Kho PCS, Man G eds). FAO Asia-Pacific Forestry Commission, Bangkok, Thailand, pp. 125-140.

Du Toit JT, Walker BH, Campbell BM (2004). Conserving tropical nature: current challenges for ecologists. Trends in Ecology Evolution 19: 12-17. - doi: 10.1016/j.tree.2003.09.018

Thomas S, Dargusch P, Harrison S, Herbohn J (2010). Why are there so few afforestation and reforestation clean development mechanism projects? Land Use Policy 27: 880-887. - doi: 10.1016/j.landusepol.2009.12.002

Turpie KJ, Marais C, Blignaut NJ (2008). The working for water programme: evolution of a payments for ecosystem services mechanism that addresses both poverty and ecosystem service delivery in South Africa. Ecological Economics 65: 788-798. - doi: 10.1016/j.ecolecon. 2007. 12.024

UNFCCC (2009). Copenhagen Accord. Web Site. [online] URL: http://unfccc.int/files/meetings/ cop_15/application/pdf/cop15_cph_auv.pdf Uryu Y, Mott C, Foread N, Yulianto K, Budiman A, Setiabudi, Takakai F, Nursamsu, Sunarto, Purastuti E, Fadhli N, Hutajulu MBC, Jaenicke J,
Hatano R, Siegert F, Stuwe M (2008). Deforestation, forest degradation, biodiversity loss and $\mathrm{CO}_{2}$ emissions in Riau, Sumatra, Indonesia. WWF Indonesia Technical Report, Jakarta, Indonesia.

Vieira LMD, Holl KD, Peneireiro MF (2009). Agro-successional restoration as a strategy to facilitate tropical forest recovery. Restoration Ecology 17: 451-459 - doi: 10.1111/j.1526100X.2009.00570.x

Villegas Z, Peña-Claros M, Mostacedo B, Alarcón A, Licona JC, Leaño C, Pariona W, Choque U (2009). Silvicultural treatments enhance growth rates of future crop trees in a tropical dry forest. Forest Ecology and Management 258: 971-977. doi: 10.1016/j.foreco.2008.10.031

Wadsworth FH, Zweede JC (2006). Liberation: acceptable production of tropical forest timber. Forest Ecology and Management 233: 45-51. doi: 10.1016/j.foreco.2006.05.072

Wellhöfer S (2002). Environmentally sound forest harvesting in Brazil - Assessment of regeneration and environmental impacts four years after harvesting. FAO Forest Harvesting Case Study 19. FAO, Rome.

Zimmerman JK, Aide MT, Lugo EA (2007). Implications of land use history for natural forest regeneration and restoration strategies in Puerto Rico. In: "Old fields: dynamics and restoration of abandoned farmland" (Cramer AV, Hobbs JR eds). Island Press, Washington, DC, USA, pp. 51-74. 